\title{
Penambahan Tepung Kedelai Pada Roti Tawar Tepung Sorgum dan Pati Garut Bebas Gluten dengan Zat Besi dan Serat Pangan
}

\author{
Wilda Khoirunnisa*', A'immatul Fauziyah ${ }^{1}$, Nanang Nasrullah ${ }^{1}$ \\ ${ }^{1}$ Program Studi Ilmu Gizi, Fakultas Ilmu Kesehatan, Universitas Pembangunan Nasional Veteran Jakarta, \\ Indonesia
}

Author's Email Correspondence (*): wildakhoirunnisa@upnvj.ac.id

\begin{abstract}
Abstrak
Kedelai merupakan biji-bijian dengan zat besi dan serat pangan sehingga dapat menaikkan kadar zat besi dan serat pangan pada produk bebas gluten untuk aman dikonsumsi oleh penderita penyakit celiac wanita dewasa. Penelitian ini bertujuan untuk menganalisis pengaruh penambahan tepung kedelai terhadap kadar zat besi dan serat pangan, mengetahui sifat organoleptik, memperoleh formula terpilih, dan mengetahui kandungan zat gizi per takaran saji formula terpilih. Penelitian ini menggunakan desain Rancangan Acak Lengkap (RAL). Analisis data kadar zat besi dan serat pangan menggunakan uji One Way ANOVA (analisis ragam) dan uji lanjut Duncan Multiple Range Test (DMRT). Analisis uji organoleptik diolah secara deskriptif. Pemilihan formula terpilih menggunakan Metode Perbandingan Eksponensial (MPE). Hasil uji anova menunjukkan bahwa penambahan tepung kedelai berpengaruh nyata $(p=0,028)$ terhadap kadar zat besi roti tawar dan tidak berpengaruh nyata $(\mathrm{p}=0,545)$ terhadap kadar serat pangan roti tawar. Formula roti tawar yang terpilih berdasarkan kadar zat besi, serat pangan, dan uji organoleptik adalah F3 (50\% tepung kedelai). Takaran saji roti tawar formula terpilih adalah 72 gram untuk 2 lembar dengan kandungan gizi sebesar 260,44 kkal energi total, 13,97 gr protein, 10,35 gr lemak, 27,83 gr karbohidrat, $3,33 \mathrm{mg}$ zat besi, dan 34,22 gr serat pangan sehingga memenuhi klaim sebagai pangan dengan zat besi dan serat pangan.
\end{abstract}

Kata Kunci: Tepung Kedelai; Zat Besi; Serat Pangan; Roti Tawar; Bebas Gluten;

How to Cite:

Khoirunnisa, W., Fauziyah, A., \& Nasrullah, N. (2021). Penambahan Tepung Kedelai Pada Roti Tawar Tepung Sorgum dan Pati Garut Bebas Gluten dengan Zat Besi dan Serat Pangan. Ghidza: Jurnal Gizi Dan Kesehatan, 5(1), 73 - 86. https://doi.org/10.22487/ghidza.v5i1.217

Published by:

Tadulako University

Address:

Soekarno Hatta KM 9. Kota Palu, Sulawesi Tengah, Indonesia.

Phone: +628525357076

Email: ghidzajurnal@gmail.com
Article history :

Received : 18022021

Received in revised form : 30062021

Accepted : 07072021

Available online 08072021 


\begin{abstract}
Soybeans are grains with iron and dietary fiber so they can increase iron and dietary fiber levels in glutenfree products to be safe for consumption by adult female celiac disease sufferers. This study aims to analyze the effect of adding soybean flour to iron and dietary fiber content, determine the organoleptic properties, obtain the selected formula, and determine the nutrient content per serving of the selected formula. This study used a completely randomized design (CRD). Data analysis of iron and dietary fiber levels used the One Way ANOVA test (analysis of variance) and the Duncan Multiple Range Test (DMRT) advanced test. Organoleptic test analysis was processed descriptively. Selection of the selected formula using the Exponential Comparison Method (MPE). Anova test results showed that the addition of soy flour had a significant effect $(\mathrm{p}=0.028)$ on the iron content of bread and had no significant effect ( $\mathrm{p}$ $=0.545$ ) on the fiber content of fresh bread. The white bread formula chosen based on iron content, dietary fiber, and organoleptic tests was F3 (50\% soy flour). The serving size of the bread with the selected formula is 72 grams for 2 pieces with a nutritional content of $260.44 \mathrm{kcal}$ of total energy, 13.97 grams of protein, 10.35 grams of fat, 27.83 grams of carbohydrates, $3.33 \mathrm{mg}$ of iron, and $34.22 \mathrm{gr}$ of food fiber so as to fulfill the claim as food with iron and dietary fiber.
\end{abstract}

Keywords: Soy Flour; Iron; Dietary Fiber; Gluten-Free; White Bread

\title{
I. PENDAHULUAN
}

Kedelai (Glycine max) merupakan salah satu jenis kacang-kacangan yang dikenal dengan kandungan proteinnya yang tinggi, yaitu sebesar 36 gram dalam 100 gramnya. Selain itu, kedelai juga mengandung mineral, salah satunya adalah zat besi. Zat besi pada 100 gram kedelai adalah sebesar 15,7 mg. Zat besi pada kedelai lebih tinggi jika dibandingkan dengan kacang-kacangan lain, seperti kacang merah segar, kacang hijau, dan kacang tanah. Selain zat besi, kedelai juga mengandung serat pangan sebesar 9 mg dalam 100 gramnya (USDA, 2018).

Tingginya zat besi pada kedelai dapat menjadi pangan alternatif untuk mencukupi kebutuhan zat besi harian. Kekurangan asupan zat besi harian masih banyak terjadi, salah satunya adalah pada penderita penyakit celiac. Penyakit celiac banyak terjadi pada wanita dewasa dan hampir $50 \%$ penderitanya mengalami defisiensi zat besi, baik yang anemia maupun tidak anemia (Oktadiana et al., 2017). Penderita penyakit celiac memiliki respon imun yang menyimpang terhadap gluten, sehingga harus menjalani diet bebas gluten (Gerdner, 2012). Diet bebas gluten memangkas semua sumber gluten seperti gandum dan turunannya yang merupakan sumber serat dan zat besi, sehingga akan mengubah komposisi gizi makro dan mikro pada produk bebas gluten (Kreutz et al., 2020). Bahkan menurut penelitian yang dilakukan oleh Newberry et al. (2017), produk bebas gluten banyak ditemukan kandungan zat gizi yang kurang, yaitu zat besi dan serat pangan. Oleh sebab itu, dibutuhkan penambahan pangan dengan sumber zat besi dan serat pangan pada produk bebas gluten, yaitu kedelai.

Kedelai dimanfaatkan dalam bentuk tepung yang memiliki keunggulan lebih mudah disimpan, volume kecil, dan dapat digunakan menjadi berbagai jenis olahan pangan. Tepung kedelai ditambahkan ke dalam pangan bebas gluten yang sering dikonsumsi, yaitu roti tawar. Menurut data Survei Sosial Ekonomi Nasional (2005), konsumsi roti tawar di Indonesia meningkat sebesar 61\%, dari sebanyak 460 juta bungkus menjadi 742 juta bungkus pada tiga tahun berikutnya pada tahun 2010 (Kurniawati \& Mustofa, 2015). 
Pada umumnya roti tawar terbuat dari tepung terigu yang merupakan produk turunan dari gandum yang menjadi pantangan bagi penderita penyakit celiac. Oleh sebab itu, dibutuhkan pengganti tepung terigu dalam pembuatan roti tawar. Tepung sorgum dan pati garut dapat dengan aman dikonsumsi oleh penderita penyakit celiac karena bebas dari kandungan gluten. Roti tawar tepung sorgum dan pati garut dengan penambahan tepung kedelai ini dikembangkan dari penelitian yang dilakukan oleh Maulida et al. (2019). Pati garut memiliki tekstur yang halus yang dapat membantu proses fermentasi adonan roti tawar bebas gluten agar dapat mengembang (Maulida et al., 2019). Pembuatan roti tawar berbahan baku tepung sorgum dan pati garut dengan penambahan tepung kedelai ini diharapkan dapat meningkatkan kandungan zat gizi makro dan mikro, yaitu zat besi dan serat pangan pada roti tawar bebas gluten. Selain itu, dengan mengonsumsi roti tawar tepung sorgum dan pati garut bebas gluten dengan penambahan tepung kedelai per takaran saji (72 gram/2 lembar) juga diharapkan dapat membantu memenuhi kebutuhan zat besi dan serat pangan harian penderita penyakit celiac wanita dewasa berumur 26-45 tahun. Penelitian ini bertujuan untuk menganalisis pengaruh penambahan tepung kedelai terhadap kadar zat besi dan serat pangan, mengetahui sifat organoleptik, menentukan formula terpilih, dan mengetahui kandungan zat gizi per takaran saji formula terpilih penambahan tepung kedelai terhadap roti tawar tepung sorgum dan pati garut bebas gluten dengan zat besi dan serat pangan.

\section{METODE}

Penelitian ini dilakukan selama 6 bulan yang dimulai dari bulan September 2020 hingga bulan Februari 2021. Persiapan formula, pembuatan sampel, dan pembuatan produk dilakukan di rumah peneliti. Uji kadar zat besi dilakukan di Balai Besar Industri Agro, Juanda, Bogor. Uji kadar serat pangan dilakukan di Laboratorium Jasa Pengujian, Kalibrasi dan Sertifikasi, Institut Pertanian Bogor. Uji proksimat (kadar air, abu, protein, lemak, dan karbohidrat) dilakukan di PT. Saraswanti Indo Genetech, Jakarta. Uji organoleptik secara hedonik dilakukan di masing-masing rumah panelis dikarenakan situasi pandemi COVID-19.

Penelitian ini menggunakan Rancangan Acak Lengkap (RAL) dengan bentuk umum yang digunakan yaitu:

$$
\mathrm{Y}_{\mathrm{ij}}=\mu+\tau_{\mathrm{i}}+\varepsilon_{\mathrm{ij}}
$$

$\mathrm{Y}_{\mathrm{ij}}=$ Hasil pengamatan respon pengaruh penambahan tepung kedelai $(30 \%, 40 \%, 50 \%)$ terhadap roti tawar tepung sorgum dan pati garut bebas gluten

$\mu=$ Nilai rataan umum

$\tau_{\mathrm{i}}=$ Pengaruh tingkat penambahan tepung kedelai $(30 \%, 40 \%, 50 \%)$ terhadap roti tawar tepung sorgum dan pati garut bebas gluten

$\varepsilon_{\mathrm{ij}}=$ Kesalahan percobaan dari perlakuan keseluruhan

$\mathrm{i}=$ Perlakuan yang dilakukan yaitu tingkatan persentase penambahan tepung kedelai (i=30\%, 40\%, 50\%)

$\mathrm{j}=$ Ulangan dari masing-masing perlakuan $(\mathrm{j}=1,2)$ 
Alat yang digunakan untuk membuat produk pada penelitian ini adalah baskom, mangkok besar, mangkok kecil, sendok, pisau, spatula kue, mixer, loyang roti tawar, oven, gelas takar, dan kain penutup. Lalu alat yang digunakan untuk analisis zat gizi adalah timbangan digital, cawan porselen, oven, desikator, tanur, api bunsen, labu kjeldahl, alat destiasi, erlenmenyer, soxhlet, kertas saring, labu takar, spectrophotometer, penangas listrik, penyaring vakum, cawan aluminium. Sedangkan alat yang digunakan untuk melakukan uji organoleptik produk adalah formulir organoleptik dan semua sampel produk dengan formula yang berbeda-beda.

Bahan yang digunakan untuk membuat produk pada penelitian ini adalah tepung sorgum (Timurasa, Purwakarta), tepung kedelai (Hasil Bumiku, Yogyakarta), pati garut (Lingkar Organik, Yogyakarta), gum arab, air, telur, susu full cream bubuk, minyak sayur, gula, garam, ragi instan, dan perisa vanilla. Lalu bahan yang digunakan untuk analisis zat gizi adalah $\mathrm{HgO}, \mathrm{K} 2 \mathrm{SO} 4, \mathrm{H} 2 \mathrm{SO} 4, \mathrm{NaOH}-\mathrm{Na} 2 \mathrm{~S} 2 \mathrm{O} 3, \mathrm{H} 3 \mathrm{BO}$, $\mathrm{HCl}$, buffer fosfat, enzim termamil, enzim protease, enzim amilogukosidase, etanol, hexane, aseton, dan akuades.

Produk roti tawar tepung sorgum dan pati garut bebas gluten dibuat dengan beberapa tahapan. Tahapan pertama adalah pembuatan roti tawar tepung sorgum dan pati garut bebas gluten dengan penambahan tepung kedelai. Selanjutnya produk roti tawar dilakukan pengujian analisis kadar zat besi dan serat pangan, serta pengujian sifat organoleptik untuk selanjutnya dilakukan penentuan formula terpilih. Tahapan terakhir adalah dilakukannya uji proksimat dan perhitungan kandungan zat gizi per takaran saji pada produk dengan formula terpilih.

Formulasi penambahan tepung kedelai pada penelitian ini didasarkan menurut peraturan BPOM (2016), bahwa suatu pangan bentuk padat dapat dikatakan sebagai sumber zat besi jika mengandung $15 \%$ ALG (22 mg), yaitu sebanyak 3,3 mg dan dikatakan sebagai pangan sumber serat pangan jika mengandung sebesar 3 gram serat pangan per 100 gram produk. Kata "sumber" pada klaim pangan olahan dapat digantikan dengan kata yang sepadan, seperti "mengandung" atau kata "dengan".

Panelis organoleptik yang berpartisipasi adalah 30 mahasiswa S1 Ilmu Gizi UPN Veteran Jakarta dengan syarat telah mendapatkan materi praktikum uji organoleptik pada mata kuliah teknologi pangan dan bersedia secara sadar. Skala hedonik pada penelitian ini menggunakan skala ganjil dimulai dari sangat tidak suka (1), tidak suka (2), biasa (3), suka (4), dan sangat suka (5) untuk memperoleh skala yang seimbang (Wijana et al., 2014). Jika nilai produk yang didapatkan lebih dari 3,00, maka produk dapat dikatakan disukai oleh panelis. Parameter yang diuji terhadap produk pada penelitian ini adalah warna, aroma, rasa, dan tekstur.

Analisis data hasil pengujian kadar zat besi dan kadar serat pangan menggunakan analisis ragam (One Way ANOVA (analysis of variance)) pada derajat kepercayaan 95\%, jika memiliki perbedaan akan dilanjutkan menggunakan analisis Duncan Multiple Range Test (DMRT) pada derajat kepercayaan 95\% untuk mengetahui perlakuan mana yang berpengaruh nyata. Untuk mengetahui sifat organoleptik dari produk penelitian, data hasil uji organoleptik secara hedonik dilakukan analisis secara deskriptif berdasarkan nilai modus dan jumlah persentase panelis. 
Metode yang digunakan untuk menentukan formula terpilih penambahan tepung kedelai terhadap roti tawar tepung sorgum dan pati garut bebas gluten adalah Metode Perbandingan Eksponensial (MPE) dengan melihat nilai hasil uji organoleptik hedonik, uji kadar zat besi, dan uji kadar serat pangan. MPE digunakan berdasarkan beberapa syarat keputusan untuk mengambil hasil akhir untuk menentukan peringkat atau ranking. Data hasil akan diberi peringkat dari terkecil hingga terbesar. Semakin kecil nilai pada peringkat, semakin mendekati nilai yang diharapkan. Total jumlah semua nilai pada setiap formula akan dilihat nilai terendahnya yang akan ditetapkan sebagai formula terpilih. Semua data pada penelitian ini diolah menggunakan aplikasi SPSS 16 dan Microsoft Excel 2010.

\section{HASIL}

\section{Perbandingan Hasil Roti Tawar}

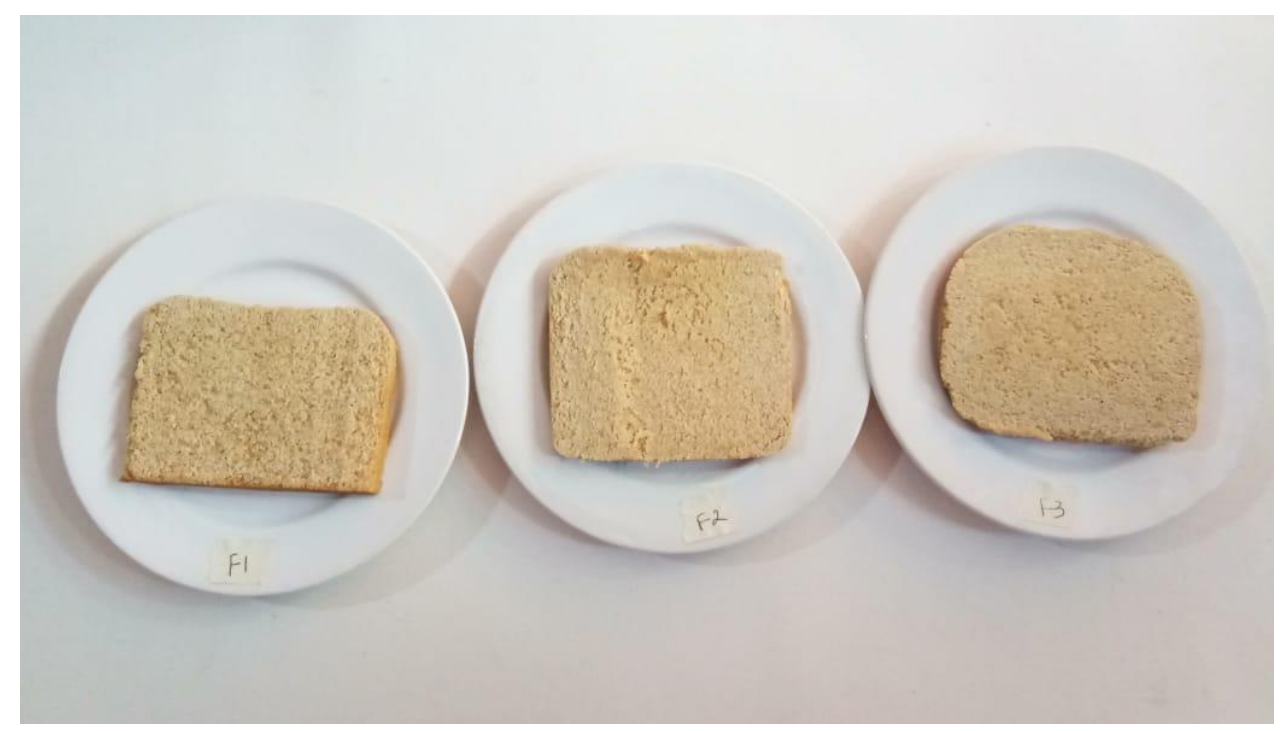

Gambar 1 Perbandingan Warna Roti

Roti tawar memiliki warna yang serupa. Hal ini disebabkan oleh warna kuning muda pada tepung kedelai. Proporsi tepung kedelai yang lebih banyak dibandingkan tepung sorgum dan pati garut menjadikan roti tawar berwarna kuning kecoklatan pada ketiga sampel. Warna kuning kecoklatan pada roti tawar disebabkan karena adanya pigmen kuning pada tepung kedelai dan terjadinya reaksi Maillard saat proses pemanggangan (Taghdir et al., 2016).

\section{Hasil Analisis Kandungan Zat Besi dan Serat Pangan}

Analisis kadar zat besi yang dilakukan menggunakan metode Atomic Absorbsion Spectrofotometry $(A A S)$, sedangkan analisis kadar serat pangan yang dilakukan menggunakan metode enzimatis sesuai dengan AOAC (2012). Hasil analisis kadar zat besi dan serat pangan pada roti tawar tepung sorgum dan pati garut bebas gluten dengan penambahan tepung kedelai tersaji pada Tabel 1. 
Tabel 1. Hasil Analisis Kadar Zat Besi dan Serat Pangan

\begin{tabular}{ccccc}
\hline Komponen & \multicolumn{3}{c}{ Sampel } & $\begin{array}{c}\text { Roti } \\
\text { Tawar } \\
\text { Acuan }^{*}\end{array}$ \\
\cline { 2 - 4 } & $\mathrm{F} 1$ & $\mathrm{~F} 2$ & $\mathrm{~F} 3$ & 3,15 \\
\hline $\begin{array}{c}\text { Zat Besi (Fe) } \\
(\mathrm{mg} / 100 \mathrm{~g})\end{array}$ & $3,82 \pm 0,071^{\mathrm{a}}$ & $4,22 \pm 0,247^{\mathrm{ab}}$ & $4,63 \pm 0,035^{\mathrm{b}}$ & 2,27 \\
\hline $\begin{array}{c}\text { Serat Pangan } \\
(\mathrm{g} / 100 \mathrm{~g})\end{array}$ & $44,78 \pm 1,329^{\mathrm{a}}$ & $47,40 \pm 2,263^{\mathrm{a}}$ & $47,50 \pm 3,642^{\mathrm{a}}$ & 2 \\
\hline
\end{tabular}

Keterangan:

f1 = penambahan tepung kedelai sebanyak $30 \%$

$\mathrm{f} 2=$ penambahan tepung kedelai sebanyak $40 \%$

$\mathrm{f} 3=$ penambahan tepung kedelai sebanyak 50\%

a,b, dan c = notasi huruf yang sama pada baris yang sama berarti tidak berbeda nyata pada taraf uji Duncan memiliki nilai $5 \%$

"Roti tawar acuan berdasarkan penelitian Khating dkk., (2014)

\section{Kadar Zat Besi}

Berdasarkan Tabel 1, kadar zat besi pada setiap sampel roti tawar F1, F2, dan F3 adalah sebesar 3,82 mg; 4,22 mg; dan 4,63 mg secara berturut-turut. Roti tawar F3 dengan penambahan tepung kedelai sebanyak 50\% memiliki kadar zat besi tertinggi, sedangkan kadar zat besi terendah terdapat pada roti tawar F1 dengan penambahan tepung kedelai sebanyak 30\%. Berdasarkan hasil analisis ragam, penambahan tepung kedelai berpengaruh secara nyata terhadap kadar zat besi roti tawar tepung sorgum dan pati garut bebas gluten $(\mathrm{p}=0,028)$. Oleh sebab itu, dilakukan uji lanjut Duncan Multiple Range Test (DMRT). Hasil analisis Duncan menunjukkan bahwa kadar zat besi pada sampel roti tawar F1 tidak berbeda secara nyata dengan sampel roti tawar F2, namun terdapat perbedaan secara nyata dengan sampel roti tawar F3. Lalu kadar zat besi pada sampel roti tawar F2 tidak berbeda secara nyata dibandingkan dengan sampel roti tawar F3.

\section{Kadar Serat Pangan}

Berdasarkan Tabel 1, kadar serat pangan pada setiap sampel roti tawar F1, F2, dan F3 adalah sebesar 44,78 mg; 47,40 mg; dan 47,50 mg secara berturut-turut. Roti tawar F3 dengan penambahan tepung kedelai sebanyak 50\% memiliki kadar serat pangan tertinggi, sedangkan kadar serat pangan terendah terdapat pada roti tawar F1 dengan penambahan tepung kedelai sebanyak 30\%. Berdasarkan hasil analisis ragam, penambahan tepung kedelai tidak berpengaruh secara nyata terhadap kadar serat pangan roti tawar tepung sorgum dan pati garut bebas gluten $(\mathrm{p}=0,545)$.

\section{Hasil Uji Organoleptik Hedonik}

Untuk mengetahui sifat organoleptik dari produk penelitian, data hasil uji organoleptik secara hedonik dilakukan analisis secara deskriptif berdasarkan nilai modus dan jumlah persentase panelis. Hasil uji organoleptik secara hedonik tersaji pada Tabel 2. 
Tabel 2. Hasil Uji Hedonik

\begin{tabular}{ccccccc}
\hline \multirow{2}{*}{ Parameter } & \multicolumn{7}{c}{$\begin{array}{c}\text { Nilai Modus Uji Hedonik Roti Tawar Tepung Sorgum dan Pati } \\
\text { Garut dengan Penambahan Tepung Kedelai }\end{array}$} \\
\cline { 2 - 8 } & \multicolumn{7}{c}{ F1 } & \multicolumn{3}{c}{ F2 } & F3 \\
\hline & Nilai & $\%$ & Nilai & $\%$ & Nilai & $\%$ \\
\hline Warna & 4 & 66,7 & 4 & 56,7 & 4 & 53,3 \\
\hline Aroma & 4 & 46,7 & 3 & 46,7 & 3 & 43,3 \\
\hline Rasa & 3 & 53,3 & 3 & 30 & 3 & 40 \\
\hline Tekstur & 2 & 43,3 & 2 & 50 & 3 & 30 \\
\hline
\end{tabular}

Keterangan:

f1 $=$ penambahan tepung kedelai sebanyak $30 \%$

$\mathrm{f} 2=$ penambahan tepung kedelai sebanyak $40 \%$

$\mathrm{f} 3=$ penambahan tepung kedelai sebanyak $50 \%$

Nilai 1 = sangat tidak suka; 2 = tidak suka; 3 = biasa; 4 = suka; 5 = sangat suka;

\section{Penentuan Formula Terpilih}

Penentuan formula terpilih dilakukan menggunakan Metode Perbandingan Eksponensial (MPE) dengan melihat nilai hasil uji kadar zat besi, kadar serat pangan, dan uji organoleptik hedonik. MPE digunakan berdasarkan beberapa syarat keputusan untuk mengambil hasil akhir untuk menentukan peringkat atau ranking. Data hasil akan diberi peringkat dari terkecil hingga terbesar. Semakin kecil nilai pada peringkat, semakin mendekati nilai yang diharapkan. Formula dengan hasil analisis terbaik diberi ranking 1, sedangkan formula dengan hasil analisis terendah diberi ranking 3 . Total jumlah semua nilai pada setiap formula akan dilihat nilai terendahnya yang akan ditetapkan sebagai formula terpilih.

Bobot yang diberikan berbeda pada setiap parameter, dengan mempertimbangkan parameter yang ingin diunggulkan dari produk roti tawar pada penelitian ini. Peneliti memberi nilai bobot sebesar $10 \%$ untuk parameter warna, aroma, rasa dan tekstur; dan nilai bobot sebesar 30\% untuk parameter kadar zat besi dan serat pangan. Pengurutan data masing-masing bobot dilakukan secara descending. Setiap parameter akan diberikan ranking berdasarkan hasil analisisnya. Lalu ranking dikalikan dengan nilai bobot pada setiap parameter. Total skor setiap formula diperoleh dari hasil penjumlahan skor pada masing-masing formula. Formula dengan total nilai skor tertinggi mendapat ranking terendah, sedangkan formula dengan total nilai skor terendah mendapat ranking tertinggi. Formula dengan ranking tertinggi dapat ditetapkan sebagai formula terpilih. Hasil uji ranking kadar zat besi, serat pangan, dan uji hedonik roti tawar tepung sorgum dan pati garut bebas gluten dengan penambahan tepung kedelai tersaji pada Tabel 3.

Tabel 3. Hasil Uji Ranking Kadar Zat Besi, Serat Pangan, dan Uji Hedonik

\begin{tabular}{lccccccc}
\hline & & \multicolumn{7}{c}{ Skor Formula } \\
\cline { 3 - 9 } Parameter & \multirow{2}{*}{ Bobot } & \multicolumn{2}{c}{ F1 } & \multicolumn{3}{c}{ F2 } & \multicolumn{2}{c}{ F3 } \\
\cline { 3 - 9 } & & Ranking & Skor $^{*}$ & Ranking & Skor & Ranking & Skor $^{*}$ \\
\hline Warna & $10 \%$ & 1 & 0,1 & 2 & 0,2 & 3 & 0,3 \\
\hline Aroma & $10 \%$ & 1 & 0,1 & 2 & 0,2 & 3 & 0,3 \\
\hline Rasa & $10 \%$ & 1 & 0,1 & 3 & 0,3 & 2 & 0,2 \\
\hline Tekstur & $10 \%$ & 3 & 0,3 & 2 & 0,2 & 1 & 0,1 \\
\hline
\end{tabular}




\begin{tabular}{lccccccc}
\hline & & \multicolumn{7}{c}{ Skor Formula } \\
\cline { 3 - 9 } Parameter & \multirow{2}{*}{ Bobot } & \multicolumn{2}{c}{ F1 } & \multicolumn{2}{c}{ F2 } & \multicolumn{2}{c}{ F3 } \\
\cline { 3 - 9 } & & Ranking & Skor $^{*}$ & Ranking & Skor & Ranking & Skor $^{*}$ \\
\hline Zat Besi & $30 \%$ & 3 & 0,9 & 2 & 0,6 & 1 & 0,3 \\
\hline $\begin{array}{l}\text { Serat } \\
\text { Pangan }\end{array}$ & $30 \%$ & 3 & 0,9 & 2 & 0,6 & 1 & 0,3 \\
\hline Total & $100 \%$ & - & 2,4 & - & 2,1 & - & 1,5 \\
\hline Ranking & - & - & $\mathbf{3}$ & - & $\mathbf{2}$ & - & $\mathbf{1}$ \\
\hline
\end{tabular}

Keterangan: *Skor diperoleh dari perkalian antara nilai bobot dengan ranking masing-masing parameter.

Berdasarkan hasil uji ranking, nilai ranking dari masing-masing parameter untuk formula F1, F2, dan F3 adalah tiga, dua, satu. Roti tawar bebas gluten f3 dengan penambahan tepung kedelai sebanyak $50 \%$ memiliki nilai tertinggi sehingga mendapatkan ranking tertinggi. Oleh sebab itu, roti tawar bebas gluten F3 dapat ditetapkan sebagai formula terpilih.

\section{Kandungan Gizi Per Takaran Saji}

Sebelum dilakukan penentuan kandungan zat gizi per takaran saji, formula terpilih roti tawar tepung sorgum dan pati garut dengan penambahan tepung kedelai f3 dilakukan uji proksimat untuk mengetahui sifat kimia dari roti (kadar air, abu, protein, lemak, dan karbohidrat). Analisis yang dihasilkan adalah kadar air (metode gravimetri), kadar abu (metode pengabuan kering), kadar protein (metode kjeldahl), kadar lemak (metode soxhlet), dan kadar karbohidrat (metode by difference). Hasil analisis uji proksimat pada roti tawar tepung sorgum dan pati garut bebas gluten dengan penambahan tepung kedelai tersaji pada Tabel 4.

Tabel 4. Hasil Analisis Uji Proksimat

\begin{tabular}{cccc}
\hline Komponen & F3 & $\begin{array}{c}\text { SNI Roti } \\
\text { Tawar }^{*}\end{array}$ & $\begin{array}{c}\text { Roti Tawar } \\
\text { Acuan }^{* * *}\end{array}$ \\
\cline { 2 - 3 } & 24,94 & Maks. 40 & 36,10 \\
\hline Air (\%) & 2,61 & Maks. 1 & 1,57 \\
\hline Abu (\%) & 19,4 & - & 11,26 \\
\hline Protein (\%) & 14,38 & - & 4,46 \\
\hline Lemak (\%) & 38,66 & - & 46,79 \\
\hline Karbohidrat (\%) & & &
\end{tabular}

\section{Keterangan:}

*SNI 8371:2018 (Standar Nasional Indonesia, 1995)

*** Roti tawar acuan berdasarkan penelitian Khating et al. (2014)

Setelah dilakukan analisis uji proksimat, selanjutnya dilakukan penentuan takaran saji roti tawar tepung sorgum dan pati garut dengan penambahan tepung kedelai. Takaran saji roti tawar tepung sorgum dan pati garut bebas gluten dengan penambahan tepung kedelai adalah sebesar 72 gram untuk 2 lembar dengan mempertimbangkan kadar zat besi dan serat pangan agar dapat mendapatkan klaim sumber zat besi dan serat pangan per 72 gram roti tawar. Kandungan gizi pada roti tawar akan dibandingkan dengan Acuan Label Gizi (ALG) untuk kelompok umum. Menurut BPOM RI (2016), ALG digunakan sebagai perhitungan persentase Angka Kecukupan Gizi (AKG) untuk perhitungan klaim bersyarat pada label 
pangan olahan. Kandungan gizi roti tawar tepung sorgum dan pati garut bebas gluten dengan penambahan tepung kedelai per takaran saji tersaji pada Tabel 5.

Tabel 5. Kandungan Gizi Per Takaran Saji

\begin{tabular}{cccc}
\hline Komposisi & $\begin{array}{c}\text { Kandungan Gizi } \\
\text { Per 72 Gram }\end{array}$ & $\begin{array}{c}\text { Persentase ALG } \\
(\mathbf{\%})\end{array}$ & $\begin{array}{c}\text { ALG Kelompok } \\
\text { Umum }\end{array}$ \\
\hline Energi (kkal) & 260,44 & 12,11 & 2150 \\
\hline Protein (gram) & 13,97 & 23,28 & 60 \\
\hline Lemak (gram) & 10,35 & 15,45 & 67 \\
\hline $\begin{array}{c}\text { Karbohidrat } \\
\text { (gram) }\end{array}$ & 27,83 & 8,56 & 325 \\
\hline Zat Besi (gram) & 3,33 & 15,14 & 22 \\
\hline $\begin{array}{c}\text { Serat Pangan } \\
\text { gram) }\end{array}$ & 34,22 & 114,07 & 30 \\
\hline
\end{tabular}

\section{PEMBAHASAN}

\section{Kadar Zat Besi}

Kadar zat besi pada setiap sampel mengalami kenaikan seiring dengan pertambahan tepung kedelai. Hal ini disebabkan oleh tingginya kadar zat besi pada 100 gram tepung kedelai, yaitu sebesar 8,4 mg (Panganku, 2018). Bahkan menurut penelitian yang dilakukan oleh Rekha et al. (2019), kandungan zat besi pada tepung kedelai lebih tinggi $(9,24 \mathrm{mg} / 100 \mathrm{~g})$ jika dibandingkan dengan tepung sorgum $(3,36$ $\mathrm{mg} / 100 \mathrm{~g})$, tepung milet atau jewawut $(3,9 \mathrm{mg} / 100 \mathrm{~g})$, tepung amarant $(7,6 \mathrm{mg} / 100 \mathrm{~g})$, dan tepung oat $(4,27 \mathrm{mg} / 100 \mathrm{~g})$. Hal ini sejalan dengan penelitian yang dilakukan oleh Farzana \& Mohajan (2015) dan Bolarinwa et al. (2016), bahwa terdapat pengaruh terhadap kenaikan kadar zat besi seiring dengan bertambahnya tepung kedelai pada kue.

\section{Kadar Serat Pangan}

Kadar serat pangan roti tawar mengalami kenaikan di setiap formulanya. Kenaikan kadar serat pangan dapat dipengaruhi oleh tingginya kadar serat pangan yang terkandung pada tepung kedelai. Kadar serat pangan pada tepung kedelai adalah sebesar 10,55 gram dan lebih besar kadarnya jika dibandingkan dengan tepung kacang merah (5,5 g/100 g), tepung jagung (3,06 g/100 g), dan tepung terigu $(2,13 \mathrm{~g} / 100$ g) (Dwi et al., 2014). Naiknya kadar serat pangan akibat penambahan tepung kedelai sesuai dengan penelitian yang dilakukan oleh Noviasari et al. (2016) dan (Dwi et al., 2014), bahwa penambahan tepung kedelai dapat meningkatkan kadar serat pangan pada beras analog dan kue. 


\section{Hasil Uji Organoleptik Hedonik Parameter Warna}

Warna merupakan salah satu parameter pada uji organoleptik untuk menilai kualitas suatu produk pangan. Warna dapat menjadi tampilan pertama bagi konsumen untuk memilih suatu produk. Menurut Lilis Agustina \& Suzanna Primadona (2018), selera konsumen dapat dipengaruhi oleh warna sehingga akan meningkatkan selera makan. Berdasarkan Tabel 2, parameter warna pada setiap sampel roti tawar F1, F2, dan F3 memiliki nilai modus dan jumlah persentase panelis masing-masing sebesar 4 (66,7\%), 4 $(56,7 \%)$, dan $4(53,3 \%)$.

Jumlah persentase panelis tertinggi $(66,7 \%)$ pada roti tawar F1 dipengaruhi oleh jumlah penambahan tepung kedelai paling sedikit yaitu sebanyak 30\%, sehingga warna kuning pada roti tawar yang dihasilkan tidak sepekat roti tawar F2 dan F3. Hal ini sejalan dengan penelitian yang dilakukan oleh Bolarinwa et al. (2016), bahwa tingkat kesukaan terhadap parameter warna biskuit semakin menurun seiring dengan bertambahnya tepung kedelai dan tepung sorgum.

Ketiga sampel roti tawar disukai dalam segi warna. Meskipun nilai modus untuk ketiga sampel adalah 4 (suka), namun sampel F1 dengan penambahan tepung kedelai sebanyak 30\% memiliki jumlah persentase panelis terbanyak, yaitu sebanyak $66,7 \%$. Jumlah persentase panelis pada parameter warna setiap sampel semakin menurun seiring dengan bertambahnya tepung kedelai pada roti tawar.

\section{Hasil Uji Organoleptik Hedonik Parameter Aroma}

Aroma menjadi salah satu hal yang diperlukan bagi konsumen yang ingin membeli, mencoba, atau memilih makanan. Kelezatan suatu makanan seringkali ditentukan oleh aroma makanan tersebut (Panjaitan et al., 2020). Berdasarkan hasil uji hedonik, parameter aroma pada setiap sampel roti tawar F1, F2, dan F3 memiliki nilai modus dan jumlah persentase panelis masing-masing sebesar 4 (46,7\%), 3 $(46,7 \%)$, dan 3 (43,3\%). Hal ini menunjukkan bahwa hanya sampel roti tawar F1 dengan penambahan tepung kedelai sebesar 30\% yang disukai dalam segi aroma. Roti tawar sampel F2 dan F3 dengan penambahan tepung kedelai masing-masing 40\% dan 50\% memiliki nilai modus 3 (biasa), namun jumlah persentase panelis pada roti tawar F2 memiliki nilai tertinggi, yaitu 46,7\%. Nilai modus pada parameter aroma setiap sampel semakin menurun seiring dengan bertambahnya tepung kedelai pada roti tawar.

Roti tawar F1 dengan nilai modus tertinggi, yaitu 4 (suka) dipengaruhi oleh jumlah penambahan tepung kedelai yang paling sedikit, yaitu sebesar 30\% dibandingkan roti tawar F2 (40\%) dan F3 (50\%). Ketiga sampel roti tawar ditambahkan dengan perisa vanilla dengan jumlah yang sama untuk menambahkan aroma sedap. Namun tepung kedelai memiliki aroma yang khas disebabkan karena adanya senyawa antigizi dan senyawa penyebab off-flavor, sehingga penambahan tepung kedelai yang lebih banyak akan mengurangi aroma meskipun sudah ditambahkan perisa vanilla (Taghdir et al., 2016). Hal ini sejalan dengan penelitian yang dilakukan oleh Taghdir et al. (2016), bahwa tingkat kesukaan terhadap aroma roti semakin menurun seiring dengan bertambahnya tepung kedelai.

\section{Hasil Uji Organoleptik Hedonik Parameter Rasa}


Rasa merupakan parameter pada uji organoleptik yang menggunakan indera perasa, yaitu lidah. Tingkat sensitivitas terhadap indera perasa pada masing-masing individu dapat berbeda. Sehingga dapat mempengaruhi hasil dari nilai uji untuk parameter rasa (Sidi et al., 2014). Berdasarkan hasil uji hedonik, parameter rasa pada setiap sampel roti tawar F1, F2, dan F3 memiliki nilai modus dan jumlah persentase panelis masing-masing sebesar $3(53,3 \%), 3(30 \%)$, dan 3 (40\%). Hal ini menunjukkan bahwa ketiga sampel roti tawar memiliki tingkat kesukaan yang biasa dalam segi rasa. Ketiga sampel memiliki nilai modus yang sama, yaitu 3 (biasa). Namun, sampel roti tawar F1 dengan penambahan tepung kedelai sebesar 30\% memiliki jumlah persentase panelis yang tertinggi $(53,3 \%)$. Ketiga sampel roti tawar ditambahkan dengan gula pasir dengan jumlah yang sama untuk menambahkan cita rasa manis. Rasa yang netral (biasa) pada ketiga sampel disebabkan oleh rasa pahit akibat adanya rasa beany atau langu pada tepung kedelai yang lebih dominan, meskipun sudah ditambahkan gula pasir (Rumapar, 2015). Hal ini sejalan dengan penelitian yang dilakukan oleh Bolarinwa et al. (2016), bahwa terdapat pengaruh terhadap penurunan tingkat kesukaan terhadap rasa kue seiring dengan bertambahnya tepung kedelai.

\section{Hasil Uji Organoleptik Hedonik Parameter Tekstur}

Tekstur merupakan salah satu penampilan suatu produk yang dapat dilihat secara langsung, selain warna. Oleh sebab itu, tekstur produk akan mempengaruhi daya terima produk dan minat konsumen (Sunarwati, 2011). Berdasarkan hasil uji hedonik, parameter tekstur pada setiap sampel roti tawar F1, F2, dan F3 memiliki nilai modus dan jumlah persentase panelis masing-masing sebesar 2 (43,3\%), 2 (50\%), dan 3 (30\%). Oleh sebab itu, roti tawar F1 dan F2 dengan penambahan tepung kedelai masing-masing sebesar 30\% dan 40\% dapat dikatakan tidak disukai dalam segi tekstur. Lalu nilai tertinggi terdapat pada roti tawar F3 dengan penambahan tepung kedelai sebesar 50\%, yaitu dengan nilai modus 3 (biasa).

Nilai modus dan jumlah persentase panelis pada parameter tekstur semakin meningkat seiring dengan bertambahnya tepung kedelai pada roti tawar. Semakin banyak penambahan tepung kedelai, maka tekstur roti tawar bebas gluten yang dihasilkan akan semakin padat dan lembut, namun pori yang dihasilkan semakin berkurang. Pori-pori pada roti tawar bebas gluten dapat dihasilkan karena adanya $\mathrm{CO} 2$ yang dihasilkan oleh ragi, serta udara yang terperangkap di adonan dibantu oleh pati garut dan gum arab (Maulida et al., 2019). Hal ini sangat berbeda dengan roti tawar mengandung gluten pada biasanya yang memiliki tekstur seperti kapas, ringan, dan berpori. Gluten berpengaruh dalam menangkap gas pada adonan dalam bentuk gelembung yang akan membentuk pori-pori roti tawar (Prasetyo, 2016). Hal ini sejalan dengan penelitian yang dilakukan oleh Ejim et al. (2019), bahwa tingkat kesukaan terhadap tekstur roti tawar bebas gluten semakin berkurang seiring dengan berkurangnya tepung maizena dan bertambahnya tepung kedelai.

\section{Kandungan Gizi Per Takaran Saji}

Kadar air dalam produk pangan olahan dapat mempengaruhi penampakan, tekstur, dan cita rasa (Fauziyah, 2011). Kadar air juga dapat mempengaruhi lama daya simpan pada pangan olahan, semakin rendah kadar air, maka daya simpan pangan akan semakin lama (Nasrulloh et al., 2019). Tingginya kadar air akan memperbanyak jumlah mikroba pada roti tawar sehingga menjadi lebih cepat rusak. Berdasarkan 
tabel 3, kadar air roti tawar tepung sorgum dan pati garut bebas gluten dengan penambahan tepung kedelai sebanyak 50\% memiliki kadar air sebesar 24,94\%.

Kadar abu pada hasil analisis pangan dapat menggambarkan kandungan mineral di dalamnya (Fauziyah et al., 2017). Semakin tinggi kadar abu, maka pangan tersebut mengandung mineral yang semakin tinggi. Berdasarkan tabel 3, roti tawar tepung sorgum dan pati garut bebas gluten dengan penambahan tepung kedelai sebanyak 50\% memiliki kadar abu sebesar 2,61\%.

Protein adalah bagian dari semua sel hidup yang menjadi bagian tubuh terbesar setelah air. Protein memiliki fungsi penting, yaitu sebagai pembangun dan pemelihara sel-sel dan jaringan tubuh. Fungsi protein ini tidak dapat digantikan oleh zat gizi lain (Almatsier, 2016). Berdasarkan tabel 3, roti tawar tepung sorgum dan pati garut bebas gluten dengan penambahan tepung kedelai sebanyak $50 \%$ memiliki kadar protein sebesar $19,4 \%$. Bahan-bahan dalam pembuatan roti tawar bebas gluten seperti tepung kedelai, tepung sorgum, susu bubuk, dan telur menyumbang kontribusi protein yang cukup tinggi. Hal ini yang dapat mempengaruhi nilai kadar protein pada roti tawar tepung sorgum dan pati garut bebas gluten dengan penambahan tepung kedelai.

Lemak dalam pembuatan produk pangan olahan, seperti kue atau roti berfungsi sebagai pengempuk dan membantu pengembangan susunan fisik makanan yang dibakar hingga volume menjadi bertambah besar (Suhardjito, 2005 dalam Yulia \& Anni, 2020). Selain itu, lemak juga dapat memberikan cita rasa, aroma, dan tekstur pada pangan olahan. Berdasarkan tabel 3, roti tawar tepung sorgum dan pati garut bebas gluten dengan penambahan tepung kedelai sebanyak 50\% memiliki kadar lemak sebesar 14,38\%.

Karbohidrat merupakan sumber penghasil energi utama selain lemak dan protein. Berdasarkan tabel 3, roti tawar tepung sorgum dan pati garut bebas gluten dengan penambahan tepung kedelai sebanyak 50\% memiliki kadar karbohidrat sebesar 38,66\%.

Takaran saji merupakan jumlah suatu olahan pangan yang aman dikonsumsi dalam satu kali makan. Satuan takaran saji dinyatakan dalam satuan Ukuran Rumah Tangga (URT) yang tepat untuk olahan pangan tersebut (Badan Pengawas Obat dan Makanan Republik Indonesia, 2019). Takaran saji produk roti tawar bebas gluten pada penelitian ini ditentukan sesuai dengan Peraturan Badan Pengawas Obat dan Makanan Nomor 22 Tahun 2019 Tentang Informasi Nilai Gizi Pada Label Pangan Olahan, yaitu sebesar 40 - 100 gram (Badan Pengawas Obat dan Makanan Republik Indonesia, 2019).

Takaran saji roti tawar formula terpilih sebesar 72 gram untuk 2 lembar telah memenuhi 12,11\% ALG energi, 23,28\% ALG protein, 15,45\% ALG lemak, 8,56\% ALG karbohidrat, 15,14\% ALG zat besi, dan 114,07\% ALG serat pangan. Roti tawar tepung sorgum dan pati garut bebas gluten dengan penambahan tepung kedelai telah memenuhi syarat klaim sebagai pangan sumber zat besi dan serat pangan menurut BPOM (2016). Pembuatan roti tawar berbahan baku tepung sorgum dan pati garut dengan penambahan tepung kedelai ini dapat meningkatkan kandungan zat gizi makro dan mikro, yaitu zat besi dan serat pangan pada roti tawar bebas gluten. Selain itu, dengan mengonsumsi roti tawar tepung sorgum dan pati garut bebas gluten dengan penambahan tepung kedelai per takaran saji (72 gram/2 lembar) diharapkan dapat membantu memenuhi kebutuhan zat besi dan serat pangan harian penderita penyakit celiac wanita dewasa berumur 26-45 tahun. (Depkes RI, 2009). 


\section{KESIMPULAN}

Penambahan tepung kedelai terdapat pengaruh yang nyata $(\mathrm{p}=0,028)$ terhadap kadar zat besi dan tidak terdapat pengaruh yang nyata $(\mathrm{p}=0,545)$ terhadap kadar serat pangan roti tawar tepung sorgum dan pati garut. Penentuan formula terpilih dengan Metode Perbandingan Eksponensial (MPE) didapatkan roti tawar tepung sorgum dan pati garut bebas gluten dengan penambahan tepung kedelai F3. Kandungan gizi per takaran saji roti tawar formula terpilih (72 gram untuk 2 lembar) adalah 260,44 kkal energi total, 13,97 gr protein, 10,35 gr lemak, 27,83 gr karbohidrat, 3,33 mg zat besi, dan 34,22 gr serat pangan. Kadar zat besi pada roti tawar adalah sebesar 15,14\% dan kadar serat pangan sebesar 114,07\%, sehingga telah memenuhi syarat klaim sebagai pangan dengan zat besi dan serat pangan menurut BPOM (2016). Pembuatan roti tawar berbahan baku tepung sorgum dan pati garut dengan penambahan tepung kedelai ini dapat meningkatkan kandungan zat gizi makro dan mikro, yaitu zat besi dan serat pangan pada roti tawar bebas gluten. Selain itu, dengan mengonsumsi roti tawar tepung sorgum dan pati garut bebas gluten dengan penambahan tepung kedelai per takaran saji (72 gram/2 lembar) diharapkan dapat membantu memenuhi kebutuhan zat besi dan serat pangan harian penderita penyakit celiac wanita dewasa berumur 26-45 tahun.

\section{DAFTAR PUSTAKA}

Almatsier, S. (2016). Prinsip Dasar Ilmu Gizi. Jakarta: Gramedia Pustaka Utama.

Badan Pengawas Obat dan Makanan Republik Indonesia. (2019). Peraturan Badan Pengawas Obat Dan Makanan Nomor 22 Tahun 2019 Tentang Informasi Nilai Gizi Pada Label Pangan Olahan. Badan Pengawas Obat Dan Makanan, 53, 1689-1699.

Bolarinwa, I. F., Abioye, A. O., Adeyanju, J. A., \& Kareem, Z. O. (2016). Production and Quality Evaluation of Biscuits Produced from Malted Sorghum-Soy Flour Blends. Journal of Advances in Food Science \& Technology, 3(3), 107-113.

BPOM RI. (2016). Peraturan Kepala Badan Pengawas Obat dan Makanan Republik Indonesia Nomor 9 Tahun 2016 tentang Acuan Label Gizi. Badan Pengawasan Obat Dan Makanan Republik Indonesia, $1-28$.

Dwi, S., Andrawulan, N., \& dkk. (2014). Formulasi dan Karakterisasi Cake Berbasis Tepung Komposit Organik Kacang Merah, Kedelai, dan Jagung. Jurnal Aplikasi Teknologi Pangan, 3(2), 54-59.

Farzana, T., \& Mohajan, S. (2015). Effect of Incorporation of Soy Flour to Wheat Flour on Nutritional and Sensory Quality of Biscuits Fortified with Mushroom. Food Science and Nutrition, 3(5), 363369. https://doi.org/10.1002/fsn3.228

Fauziyah, A., Marliyati, S. A., \& Kustiyah, L. (2017). Substitusi Tepung Kacang Merah Meningkatkan Kandungan Gizi, Serat Pangan aan Kapasitas Antioksidan Beras Analog Sorgum. Jurnal Gizi Dan Pangan, 12(2), 147-152. https://doi.org/10.25182/jgp.2017.12.2.147-152

Gerdner, L. a. (2012). World Journal of Psychiatry. World Journal of Psychiatry, 2(2), 26-32. 
https://doi.org/10.5498/wjp.v2.i2.26

Kementerian Kesehatan Republik Indonesia. (2019). Peraturan Menteri Kesehatan Republik Indonesia Nomor 28 Tahun 2019 Tentang Angka Kecukupan Gizi Yang Dianjurkan Untuk Masyarakat Indonesia. Jakarta: Kementerian Kesehatan Republik Indonesia.

Khating, K. P., Kenghe, R. N., Yenge, G. B., Ingale, V. M., \& Shelar, S. D. (2014). Effect of Incorporation of Sorghum Flour on Wheat Composite Bread. Journal of Progressive Agriculture, 5(1), 93-98.

http://www.researchjournal.co.in/online/IJAE.htm\%0Ahttps://www.cabdirect.org/cabdirect/abstract/ 20143236101

Kreutz, J. M., Adriaanse, M. P. M., van der Ploeg, E. M. C., \& Vreugdenhil, A. C. E. (2020). Narrative Review: Nutrient Deficiencies in Adults and Children with Treated and Untreated Celiac Disease. Nutrients, 12(2). https://doi.org/10.3390/nu12020500

Kurniawati, L., \& Mustofa, A. (2015). Karakteristik Roti Tawar dengan Substitusi Tepung Sorgum ( Sorghum Bicolor (L) Moench) Terfermentasi dan Tanpa Fermentasi. Jurnal Teknologi Hasil Pertanian, VIII(1), 1-5.

Lilis Agustina, \& Suzanna Primadona. (2018). Hubungan Antara Rasa Makanan dan Suhu Makanan dengan Sisa Makanan Lauk Hewani Pada Pasien Anak Di Ruang Rawat Inap RUMKITAL Dr. Ramelan Surabaya. Amerta Nutrition, 2(3), 245-253. https://doi.org/10.20473/amnt.v2.i3.2018.245253

Ejim, M. N., Omachi, A. B., Odor, C. B., Abiodun, M. A., \& Obafemi, J. K. (2019). Proximate Composition and Sensory Properties of Bread Produced from Malted Maize -Soy Flour Blends. International Journal of Pure and Applied Science, 17(9), 145-155.

Maulida, Z., Aini, N., Sustriawan, B., \& Sumarmono, J. (2019). Formulasi Roti Bebas Gluten Berbasis Tepung Sorgum dengan Penambahan Pati Garut Dan Gum Arab. Jurnal Penelitian Pascapanen Pertanian, 16(2), 90. https://doi.org/10.21082/jpasca.v16n2.2019.90-98

Nasrulloh, N., Nurcahya, W. A., Marjan, A. Q., Ilmu, S., Fakultas, G., \& Kesehatan, I. (2019). Aplikasi Iradiasi Sinar Gamma untuk Menurunkan Kadar Basa Purin Adenin dan Hipoksantin Emping Melinjo ( Gnetum Gnemon L ). Jurnal Ilmu Pangan Dan Hasil Pertanian, 3(1), 12-21.

Newberry, C., McKnight, L., Sarav, M., \& Pickett-Blakely, O. (2017). Going Gluten Free: the History and Nutritional Implications of Today's Most Popular Diet. Current Gastroenterology Reports, 19(11). https://doi.org/10.1007/s11894-017-0597-2

Noviasari, S., Kusnandar, F., Setiyono, A., \& Budijanto, S. (2016). Beras Analog Sebagai Pangan Fungsional dengan Indeks Glikemik Rendah. Jurnal Gizi Dan Pangan, 10(3), 225-232. https://doi.org/10.25182/jgp.2015.10.3.

Oktadiana, H., Abdullah, M., Renaldi, K., \& Dyah, N. (2017). Diagnosis dan Tata Laksana Penyakit Celiac. Jurnal Penyakit Dalam Indonesia, 4(3), 157. https://doi.org/10.7454/jpdi.v4i3.131

Panjaitan, P. S., Panjaitan, T. F., Siregar, A. N., \& Sipahutar, Y. H. (2020). Karakteristik Mutu Tortila dengan Penambahan Rumput Laut (Eucheuma Cottonii). Aurelia Journal, 2(1), 73. 
https://doi.org/10.15578/aj.v2i1.9406

Papathanasopoulos, A., \& Camilleri, M. (2010). Dietary Fiber Supplements: Effects in Obesity and Metabolic Syndrome and Relationship to Gastrointestinal Functions. Gastroenterology, 138(1), 6572.e2. https://doi.org/10.1053/j.gastro.2009.11.045

Prasetyo, A. (2016). Pengaruh Suhu dan Waktu Proofing Terhadap Karakteristik Fisik Kimia dann Organoleptik Roti Tawar Non Gluten Berbahan Baku Tepung Uwi dan Tepung Kedelai Hitam. Skripsi Jurusan Teknologi Hasil Pertanian Fakultas Teknologi Hasil Pertanian Universitas Brawijaya.

Rekha, N., Rajkumar, R., \& Ganesh, J. (2019). Formulation and quality evaluation of multigrain bhakari premix. The Pharma Innovation Journal, 8(9), 249-254.

Rumapar, M. (2015). Fortifikasi Tepung Kedelai Pada Pembuatan Beras Instant Alternatif Berbahan Sagu Dan Cassava. Majalah Biam, 11(2), 37-48.

Sidi, N. C., Widowati, E., \& Nursiwi, A. (2014). Pengaruh Penambahan Karagenan pada Karakteristik Fisikokimia dan Sensoris Fruit Leather Nanas ( Ananas Comosus L . Merr .) dan Wortel ( Daucus Carota ). Jurnal Aplikasi Teknologi Pangan, 3(4), 122-127.

Sunarwati, D. A. (2011). Pengaruh substitusi tepung sukun terhadap kualitas brownies kukus. Skripsi Jurusan Teknologi Jasa Dan Produksi Fakultas Teknik Universitas Negeri Semarang.

Taghdir, M., Mohammad, S., Naser, M., Mojtaba, H., Ashourpour, M., \& Salehi, M. (2016). Effect of Soy Flour on Nutritional, Physicochemical, and Sensory Characteristics of Gluten-Free Bread. Food Science \& Nutrition, June, 1-7. https://doi.org/10.1002/fsn3.411

United Stated Department of Agriculture. (2020). USDA National Nutrient Database for Standart Reference. Nutrient Data of Sorghum Grain, diakses tanggal 28 November 2020 https://fdc.nal.usda.gov/fdc-app.html\#/food-details/169716/nutrients.

U. S. D. A. (2018). USDA National Nutrient Database for Standart Reference. Nutrient Data of Soybean.

Wijana, S., Mulyadi, Arie, F., \& Septivirta, Theresia, D. (2014). Pembuatan Permen Jelly dari Buah Nanas (Ananas comosus) Subgrade (Kajian Konsentrasi Karagenan dan Gelatin). Teknologi Industri Pertanian, 1(1), 1-15.

Yulia, N., \& Anni, F. (2020). Pengaruh Penggunaan Jenis Lemak Terhadap Kualitas Sponge Cake. Jurnal Kapita Selekta Geografi, 3, 1-9. 